Original Research Paper

\title{
Microspore Analysis for Genotoxicity of Polluted Atmospheric Environment ( The Case Study in The Mataram City )
}

\author{
Suripto $^{1 *}$, Kurniasih Sukenti ${ }^{1}$, Sukiman ${ }^{1}$, Immy Suci Rohyani ${ }^{2}$, Ahmad Jupri ${ }^{2}$ \\ ${ }^{1}$ Research Group in Plant Ecology, Faculty of Mathematics and Natural Scences University of Mataram, Indonesia; \\ ${ }^{2}$ Research Group in Environmental Science, Faculty of Mathematics and Natural Scences University of Mataram, \\ Indonesia
}

\author{
Riwayat artikel \\ Received : July $26^{\text {th }}, 2019$ \\ Revised : August $14^{\text {th }}, 2019$ \\ Accepted : August 19, 2019 \\ Published : August $23^{\text {th }}, 2019$ \\ *Corresponding Author: \\ Suripto, \\ Biology Study Program Faculty \\ of Mathematics and Natural \\ Sciences, University of \\ Mataram, Indonesia; \\ Email: suriptobio@unram.ac.id
}

\begin{abstract}
The need for environmental protection continues to increase, so exploratory studies of agents of polluted environmental indicators are becoming increasingly important. The advantages of using flowering plants for environmental bio-indicator studies include the availability of sufficient test material with their variations and the availability of different periods for sampling. Seven plant species were used to examine their suitability as bioindicator for genotoxicity of polluted atmospheric environment in Mataram City by microspore analysis. This study was conducted with the aim of, 1) knowing the level of difference in the frequency of failure (abortiveness) of microspores between similar plants that grow in areas at risk of being polluted in the city and those growing in areas not at risk of being polluted outside the city of Mataram, and 2) find out what types of flowering plants, especially those in city parks that are suitable as bio-indicators of air pollution for Mataram City. The percentage of aborted pollens was calculated out of 50 to 300 observed pollen grains of each selected individual flowering plant. Sample of each plant species from every study area consist of ten plant individuals. Data were analyzed by use the Wilcoxon one way-test at $\alpha 0.05$ to determine significance of difference in the percentage of aborted pollen grains from same plant species between in the risky polluted area and plant in the control area. The results showed that Lantana camara L. is suitable as bio-indicator for atmospheric pollution in Mataram City or other cities that have a density of traffic flow of motorized vehicles around 100 vehicles per hour. Its percentage of aborted pollen grains is 1,62 $\pm 0,08 \%$ in the risky polluted area, and 1,21 $\pm 0,13 \%$ in the control area. Others six observed plant spesies, i.e. Acacia auriculiformis A. Conn. Ex Bth., Bauhinia acuminata L., Baugenvillea spectabilis Willd. Duranta erecta L., Ixora coccinea L. and Rosa hybryda Hort., each of them is not suitable as bioindicator for it. Their percentage of pollen abortiveness in polluted and not-polluted areas were not different, significantly.
\end{abstract}

Keywords: Genotoxicity, Microspores, Polluted air environment

\section{Introduction}

With the increasing need for environmental protection, exploratory studies of polluted environmental indicator agents become increasingly important.

At the community level, the possibility of a plant species can or cannot be used as an indicator of an environmental factor can be determined based on the relative presence or absence of the plant species. The degree of the pattern of relationships between the presence of species and the variables of an environmental factor is the basis for determining the possibility that the plant species can be used as an indicator for an environmental factor earlier (Suripto \& Sukarso, 2003).

At the population level, the possibility of a plant species can or cannot be used as an indicator of an environmental factor, such as pollution by a material can be determined based on the evidence (evidence) influence of pollution on certain sensitive body parts of the individual population (Micieta \& Murin, 2018). 
There are also other variables from plant parts that are more significant indicating changes or abnormalities due to pollution of a material at a lower level, namely changes in the character of pollen stem cells (microspores), which are also called genotoxicity variables. Commonly observed genotoxicity variables include the number of micronuclei (Kosmider et al., 2018), and the size, shape and presence or absence of pollen staining as observed in garden plant species, namely Artemisia vylgaris, Avena sativa, Crepis tectorum, Daclytis glomerata, Festuca gigantea, Potentilla reptans, Ranunculus acris, $R$. lanuginosus Rumex acetosa, $R$. Acetocella, $R$. conglomeratus, $R$. obtusifolius, Vicia angustifolia and V. hirtusa (Maskina et al., 2016) .

The species of wild plants and cultivation of the flowering plant division (Anthophyta) are generally able to act as bioindicators of genotoxicity. The advantage of using flowering plants for bioindicator studies of environmental pollution is that sufficient number and variety of test plants are available in the study and control areas, different periods for sampling, and the in situ indication of genotoxicity can use procedures or standardized methodology. If bio-indicator plant species only have a small supply at a certain location, then sampling usually a number of these types can produce a reliable indication of genotoxicity (steady) (Micieta \& Murin, 2018).

Many flowering plant species have been used as indicators of environmental pollution based on evidence of toxic effects on these plants (Kosmider et al., 2018). However, the phytotoxicity variable used is generally only observed in cases of pollution with very high levels of pollution. In other words, the organ or part of the plant that is observed does not have enough sensitivity for the level of pollution of a lower material.

Many species of flowering plants have reproductive organs that are very sensitive to the presence of air pollutants. Air pollutants are usually sourced from the combustion of fuel in motor vehicle engines. Parts of the reproductive organs that are sensitive to air pollutants are pollen, especially in the tetrad phases.

The advantages of using plants for the study of environmental bioindicators are, among others, enough available test materials (flowering plants) with their variations and the availability of different periods for sampling. In urban areas, air pollution generally comes from motorized vehicles that run over the highway (Grant \& Zura, 2017).

In urban areas, air pollution is generally sourced by motorized vehicles that run on the highway. The city of Mataram, although included in the category of small cities, but has a high risk of pollution of the city's air environment by chemicals emitted by motorized vehicles, which packed the city. This is because the flow of motorized vehicles in the city of Mataram, especially on the main roads, mainly during the day is classified as quite dense to very dense, which ranges from 65 to 80 twowheeled motorized vehicles and 40 to 45 four-wheeled motorized vehicles every hour (Suripto, 2019). As a comparison, UNEP (2015) and De Serres (2017) have stated that highways with more than 100 motorized (motor cycles and cars) vehicles per hour have a high risk of air pollution from chemicals emitted by motorized vehicles.

The information above show that carrying out air quality monitoring for the Mataram City area is a necessity and that can't be ignored. Apart from that also because in the city of Mataram there are enough available various species of flowering plants, both as a component of city gardens as well as shade trees of the highway. Thus, the use of flowering plants as an environmental bioindicator agent in the city of Mataram is worth trying and developing. follows:

The main issues of concern in this study are as

1. What is the level of difference in the frequency of failure (abortiveness) of microspores between similar plants that grow in the City of Mataram that are at risk of being polluted in the city and those growing in the area not at risk of being polluted outside the city?

2. What species of flowering plants, especially those in city parks that are suitable as bioindicators of air pollution for the city of Mataram?

Based on the above problem formulation, this research was conducted with the following objectives:

1. To find out the level of difference in the frequency of failure (abortiveness) of microspores between similar plant species that grow in areas that are at risk of being polluted within the city and those that grow in areas that are not at risk of being polluted outside of the city of Mataram.

2. Species of flowering plants whatsoever, especially those in city parks that are suitable bio-indicators of air pollution for the city of Mataram. 


\section{Materials and Methods}

\section{Plant Selection and Sampling for Bio-indicators of Polluted Environment}

Plants of city gardens in the City of Mataram those are assumed to be at risk of air pollution and similar plants in rural areas that are assumed to be not at risk of being polluted are selected for inspection as bioindicators of air pollution.

The selection of plants is based on the criteria, that 1) plants must be diploid (pollen haploid), 2) plants must produce viable pollen (pollen abortion frequency less than $5 \%$ ), and 3) living plants settling in urban areas that are at risk of contamination or diarrhea rural areas that are not at risk of being polluted. Based on these criteria, the area of urban parks in The City of Mataram that are selected for plant observation are city gardens in The Street of Mayura, Cakranegara District, Street of Pejanggik, Mataram District, Udayana Street and Welcome Park in Ampenan District. The Pagesangan and Pagutan inland areas were chosen as control areas that are not at risk of being polluted.

Before sampling the flowering plants to be measured their pollen abortion in the laboratory, the observations of the current density of motor vehicles in each sampling area (polluted and control area) were first carried out. This has been done to verify the risk of air pollution in the sample observation area based on the density of motor vehicle traffic flow.

From each selected plant species, 10 plant individuals are proportionally collected from city gardens inside of Mataram City and from rural areas in the countryside of The Sub-Districts of Pagutan and Pagesangan.

Flower buds and young flowers from each selected plant were collected and mixed in a mixture of ethanol: acetic acid (3: 1). After 24 hours, the mixture is replaced with $75 \%$ ethanol, and the sample is stored until the next examination process.

\section{Slide Making and Observation of Pollen Abortion}

Slides and pollen abortion observations were carried out by a procedure modified from Holub \& Ostralucka (2017), as follows:

1. Flower buds, closed flowers and young flowers are removed from the mixed solution, washed and then anthera separated.

2. Pollen is removed from each anther using a needle. Pollen items are moved from the slide.

3. The pollen is colored with aniline-blue $1 \%$ in lactophenol.
In some species of plants, ripe pollen appears in the tetrad and this characteristic facilitates the way to distinguish genetic toxicity from physiological toxicity from the pollutants studied. One, two or three core pollen abortions in tetrad always indicate genetic damage, while physiological damage always affects the overall flower, anther and all of these four pollen. The basic criteria for declaring microspore abortion (pollen) are as follows (Micieta \& Murin, 2018):

1. The size of both pollen and tetrad individuals is significantly greater than normal individual pollen or tetrad.

2. The internal shape of the tetrad changes significantly, such as the number of air sacs (sacculus aereus) is more, which is from three to four.

3. Shows deficiency of staining, pollen pollutants that do not react abortion gives color.

Techniques for observing pollen samples are carried out according to Grant \& Zura (2017), which is the average percentage of pollen abortion is calculated from 10 individual plants (replications). Pollen number observed for each replication ranged from 50 to 300 pollen grains.

\section{Data Analysis}

The variable of pollen abortiveness observed is the percentage of pollen that has an abortion. Observation of the variables of each flowering plant species was carried out in sixteen replications.

Pollen abortion data from different flowering plant species are not processed in difference or are not compared. Percentage data $(\%)$ of the same flowering plant species between those living in locations at risk of being polluted in the city of Mataram and those living in locations not polluted in the Countryside (control) were processed by Wilcoxon one-way test (Zar, 1984).

Plant species that show statistically significant difference in their pollen abortiveness between those living in polluted and non-polluted areas are declared suitable as bioindicators.

The overall research work of microspore analysis for genotoxicity of polluted atmospheric environment can be seen in Figure 1. 


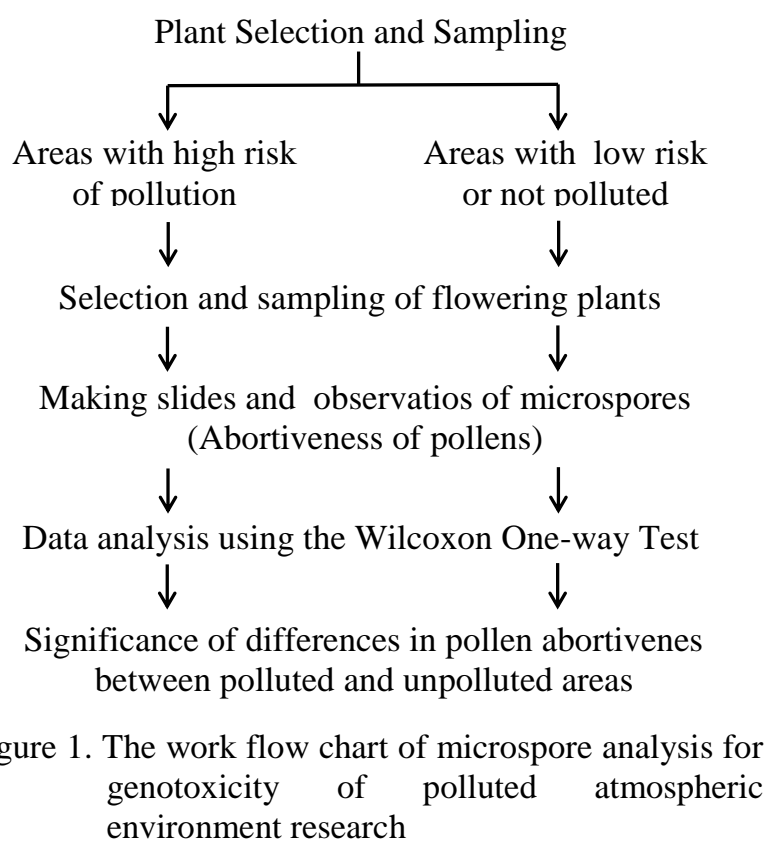

\section{Results and Discussion}

It has been stated, that although the city of Mataram is classified as a small city, it is included in the category of having a high risk of polluting the air environment by chemicals emitted by motor vehicles. The traffic flow of motorized vehicles in the daytime in these observation sample areas in Mataram City, namely Pejanggik Street, Mayura Garden Park in the District of Cakranegara, Udayana Street and Welcome Park in Ampenan District recorded around 65 to 80 motorcycles and 40 to 45 cars per hour (Table 1).

Based on these data, the highways in the city of Mataram were verified as areas that are at high risk of air pollution. Verification of the pollution risk level based on the density of vehicle currents above is in accordance with the opinion of UNEP (2015), namely that highways with more than 100 motorized vehicles (motorcycles and cars) per hour have a high risk of air pollution from chemicals emitted by motor vehicles.

Table 1. Average density of motorized traffic flow (number of vehicles passing per hour) during the day in the city of Mataram

\begin{tabular}{lcc}
\hline Observation sample area & $\begin{array}{l}\text { Motor } \\
\text { Cycle }\end{array}$ & Car \\
\hline Pejanggik Street & 74 & 45 \\
Mayura Garden Park & 65 & 40
\end{tabular}

$\begin{array}{lcc}\text { Udayana Street } & 78 & 42 \\ \text { Wellcome Park Ampenan } & 80 & 40\end{array}$

Sampling of flowering plants was also carried out in rural areas of the City of Mataram, namely in the districts of Pagutan and Pagesangan. The flow of motorized vehicles during the day in this control area was in the range of 10 to 20 two motorcycles and 5 to 10 cars (Table 2).

Table 2. Average density of motorized traffic flow (number of vehicles passing per hour) during the day in the hinterland of Mataram City (Control Area)

\begin{tabular}{lcc}
\hline Observation sample area & $\begin{array}{c}\text { Motor } \\
\text { Cycle }\end{array}$ & Car \\
\hline Inland of Pagunan District & 20 & 10 \\
Inland of Pagesangan District & 10 & 5 \\
\hline
\end{tabular}

Based on this data, these observation sample areas are verified as not at risk of being polluted.

It has been stated before, the selected study plants are plants that are normally diploid and have proper pollen. Seven species of diploid plants those with proper pollen in various city gardens in Mataram City and in areas outside the city have been obtained. The results of observations of viable and non-viable pollen can be seen in Figure 1.

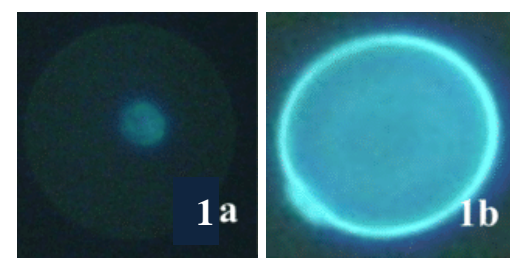

Figur 1. Viable (a) and non-viable (b) pollens

Seven species of flowering plants have been studied as bio-indicators of air pollution in The City of Mataram. Based on the criteria mentioned above, the city parks in the city of Mataram chosen for inspection i.e. like city garden in Mayura Distric, Cakranegara Regency, Pejanggik Street, Mataram Regency, Udayana Street, and "Welcome Park" in Ampenan Regency. Inland areas such as regencies of Pagesangan and Pagutan are chosen as control areas that are not at risk of being polluted. 
Table 3 shows the data on the percentage of pollen grains that has an abortion from each species of plant studied, which grows in polluted areas within city gardens in The Mataram City region and which grows outside the city as controls.

Table 3. Percentage of pollen who experience abortion in plants in polluted areas and controls

\begin{tabular}{|c|c|c|c|}
\hline \multirow[t]{2}{*}{ No. } & \multirow[t]{2}{*}{ Plant Species } & \multicolumn{2}{|c|}{ Pollen abortiveness $(\%)$} \\
\hline & & $\begin{array}{l}\text { Control } \\
\text { Area }\end{array}$ & $\begin{array}{l}\text { Polluted } \\
\text { Area }\end{array}$ \\
\hline 1. & $\begin{array}{l}\text { Acacia } \\
\text { auriculiformis A. }\end{array}$ & $1,26 \pm 0,09$ & $1,30 \pm 0,24$ \\
\hline 2. & $\begin{array}{l}\text { Bauhinia } \\
\text { acuminata } \mathrm{L} .\end{array}$ & $2,02 \pm 0,14$ & $2,04 \pm 0,21$ \\
\hline 3. & $\begin{array}{l}\text { Bougainviella } \\
\text { spectabilis Wild. }\end{array}$ & $2,42 \pm 0,22$ & $2,66 \pm 0,46$ \\
\hline 4. & Duranta erecta L. & $1,60 \pm 0,25$ & $1,78 \pm 0,10$ \\
\hline 5. & Ixora coccinea L. & $1,75 \pm 0,07$ & $1,76 \pm 0,20$ \\
\hline 6. & Lantana camara $\mathrm{L}$. & $1,21 \pm 0,13$ & $1,62 \pm 0,08 *$ \\
\hline 7 & Rosa hybrida L. & $2,04 \pm 0,22$ & $2,07 \pm 0,22$ \\
\hline
\end{tabular}

* There is a difference in the level of significance $(\alpha)$ 0.05 .

The results of this study indicate, that of the seven species these were selected and examined, only one species showed suitability as a bioindicator of air pollution, i.e. Lantara camara L. (Java:Saliara; Sunda: Tembelekan; Lombok: Selire) for areas in the City of Mataram. The data shows that the frequency (\%) of abortion of L. camara pollen powder in dense areas of motorized vehicle traffic is $1.62 \pm 0.08 \%$ and this is significantly different from the frequency of pollen abortion of plants that grow in non-congested traffic areas, which is $1.21 \pm 0.13 \%$.

Abortiveness data for the six other plant species for the same plant species did not show any significant differences in the frequency of pollen abortions between those growing in cities and those grown in rural areas (Table 3). However, the results of this study show that there are pollen abortions in plants that are studied, both those that grow in traffic-intensive areas of motor vehicles and those that grow in rural areas. Of all types of plants examined, none of the pollen powder abortiveness exceeded $2.7 \%$.

The sample of $L$. camara plant species observed in this study consisted of individuals with white, yellow and red flowering (Figure 2).

Pollen abortivity data between individual plants with different flower colors are not analyzed in difference or are not compared.

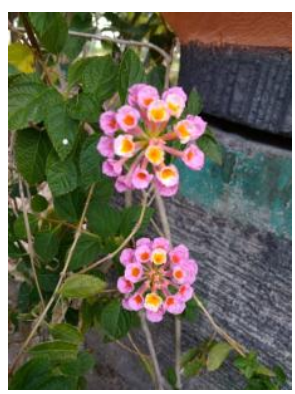

\section{The Pink Flower Individual Plant}

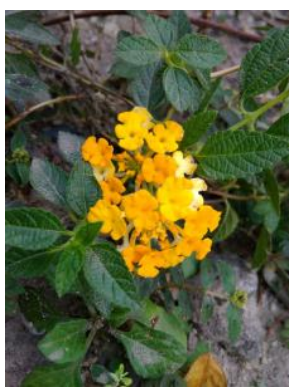

The Orange Flower Individual Plant

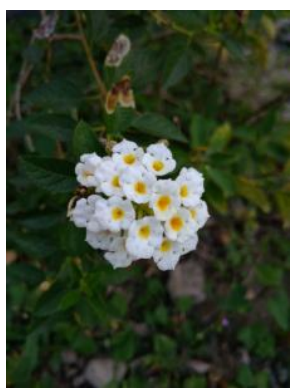

The White Flower Individual Plant

Figure 2. Habitus of Lantara camara species

In previous years indications of air pollution in the city of Mataram have also been known through microspores analysis on the same plant species, namely $L$. Camara, while other types of plants that were also examined did not show a match as an bioindicator of air pollution in the area (Suripto \& Sukarso, 2003).

Micieta \& Murin (2018) have also reported the results of a study of 41 types of garden plants through microspores analysis for genotoxicity. Of the 41 plant species observed, 20 species proved to be suitable for use as bioindicators of air pollution by motor vehicles and factories that emit Pb-containing compounds. Abortiveness of pollen powders in polluted areas ranges 
from $1.6 \pm 0.4 \%$ in Picris hieraciodes L. to $27.4 \pm 6.1 \%$ in Caluna vulgaris (L.) Holl. in the lead industrial area in Slovakia. In this study, the number of pollen in each tetrad undergoing an abortion ranged from one to three, and it was rarely found to have an abortion for all of the four pollen in the tetrad. Pollen abortion in the seven plant species examined in this study indicates genocytic damage and does not show physiological damage.

According to Holub \& Ostralucka (2017) and Mashkina et al. (2016), and Micieta \& Murin (2018), the abortion of one, two or three pollen powders in each microsporal tetrad always shows genocytic damage, meaning that abnormalities are indicated by cells or tissues of reproductive organs that have a high sensitivity to certain pollutants in the air. Meanwhile, physiological damage always or frequently results in the abortion of all of the four pollen powders in the tetrad, and even all of the anthera and its flowers.

The above results mean that pollen abortion that occurs in plants in The City of Mataram is very unlikely to be caused by air pollution due to motorized vehicles. Thus, air pollution by motorized vehicles in the city of Mataram cannot be monitored effectively using the six types mentioned above through its microscopic analysis. Whereas, L. camara can be used as a bioindicator of air pollution in The City of Mataram. This is because the abortiveness of pollen powder in dense areas of motorized vehicle traffic is significantly different from those in rural areas, although the price of abortiveness of plant pollen in the two study areas is very small.

Long before this, the indication of air pollution in the city of Mataram was also known through microspore analysis on the same type of plant, namely L. Camara, while other species of plants that were also examined did not show compatibility as bioindicators of air pollution in the area (Suripto \& Sukarso , 2003).

Micieta \& Murin (2018) and Rangaswamy et al. (2019) have also reported the results of a study of 41 types of garden plants through microspores analysis for genotoxicity. Of the 41 plant species observed, 20 species proved suitable for use as bioindicators of air pollution by motor vehicles and factories that emit compounds containing $\mathrm{Pb}$. Abortiveness of pollen powder in polluted areas ranges from $1.640 .4 \%$ in the Picris hieraciodes L. to $27.416 .1 \%$ in Caluna vulgaris (L.) Holl. in the lead industrial area in Slovakia. In this study, the number of pollen in each tetrad experiencing abortions ranged from one to three, and according to Kosmider et al. (2018).

Abortion is rarely found in all of the four pollen in the tetrad. Pollen abortion in L.camara examined indicated genocytic damage but didn't show physiologilal damage. This is due to differences in the size of the microspores tetrad (Figure 3), which indicates the presence of pollen abortion does not cause physiological disorders.

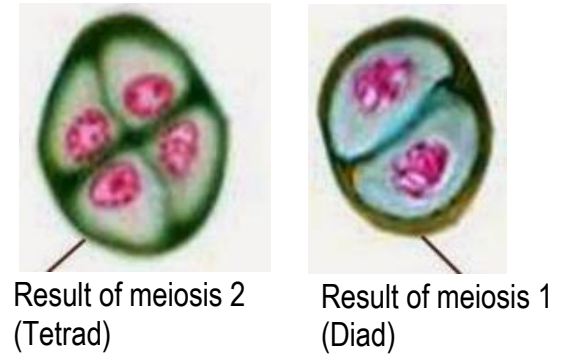

Figure 3. Microspores of L. camara

Anitasari (2019) and Ostralucka (2017) have also previously reported, that pollen abortion of other plant species indicate the presence of genocytic damage and not show physiological damage.

Holub \& Ostralucka (2017) have also reported that abortion one, two or three pollen powders in each microspor tetrad always shows genocytic damage, meaning abnormalities are shown by cells or tissues of the reproductive organs that have high sensitivity to the material - certain pollutants in the air. Whereas, physiological damage always or often results in abortion of all four pollen powders in the tetrad, and even all antheras and flowers.

By paying attention to the results of the research above, it can be concluded the benefits of this research are as follows:

1. The results provide data on selected flowering plants that are suitable and capable as air bioindicators for the city of Mataram.

2. The selected plant data can be used as basic information for the development of urban air quality monitoring systems. Specifically for the City of Mataram.

3. The data can also be used as basic information for a more in-depth study of the standardization of the determination of the type and quantity of pollutants based on the evidence that influence on microspores of test plants.

Finally, based on the results described above it can be recommended, that $L$. camara species need to be developed into the main vegetation component in city gardens as an air pollution bio-indicator agent in The City of Mataram and other cities that have vehicle traffic flows ranging from 105 to 120 motorized vehicle per hour. 


\section{Conclusions}

Seven types of garden plants have studied their suitability as bioindicators of air pollution in the Mataram City area. Each of the seven types of plants is easily found in all city parks in the city of Mataram and microscopy can be analyzed for genotoxicity.

Of the seven species of plants studied, only one species was Lantana camara L. which was proven suitable as a bioindicator of air pollution for the city of Mataram. Pollen abortion of L. camara was $1.62 \pm 0.08 \%$ in the inner city area and $1.21 \pm 0.13 \%$ in the outer city area as a control.

The other six plant species, namely Acacia auriculiformis A. Conn. ex Bth., Bougainviella spectabilis Wild., Bauhinia acuminata L., Duranta erecta L., Ixora coccinea L., Rosa hybrida L. proved to be unsuitable as a bioindicator of air pollution for the City of Mataram.

It is recommended, that the species plant, Lantara camara is recommended to be developed as a bioindicator of air environmental pollution being a major vegetation component of city park gardens inside The City of Mataram.

\section{Acknowledgment}

This research is fully supported and funded by the Ministry of Research, Technology and Higher Education, the Republic of Indonesia through The Institute for Research and Community Service and Faculty of Mathematics and Natural Sciences, University of Mataram.

Also thanks are given to students of environmental science at the Biology Study Program of the Faculty of Mathematics and Natural Sciences, University of Mataram, even semester of academic year 2018/2019.

\section{References}

Anitasari, S.D. (2017). Persiapan Tanaman Donor Kultur Mikrospora Brokoli Kultivar BL 10001. Jurnal Biologi dan Pembelajarannya. 4 (1) : 15-18. DOI:http://ojs.unpkediri.ac.id/ index.php/biologi

De Serres, F.J. (2017). Higher plants as effective monitors of environmental mutagens. Mutat. Res. $270: 1-2$. DOI:https://www.journals. elsevier.com

Grant, W.F. \& Zura, K.D. (2017). Plant as sensitive in situ detectors atmospheric mutagen. In: Mutagenecity-
Horizon In Genetic Toxicology (Heddle, J.A., Ed.). Academic Press. London. ISBN: eBook: 978-012-804771-2; p407-434.

Holub, Z. \& Ostralucka, M.G. (2017). Tolerance of pollen from trees to chronic effect of $\mathrm{Pb}$ and acidity. Biologia (Bratislava). 46:331-335. DOI: http://www.springer.com/11756.

Kosmider, B., Osiecka, R. \& Sicienski, J. (2018). Micronucleus assay in plants to monitor environmental pollution in situ. Mendel-Brno. 17 (6):9-12. DOI: http://mendelu.cz/org

Mashkina, H., Olga, M. \& Butiloria, L. \& Anastasya, (2016). Cytological mechanisms of unreduced microspore formation in tree species. Cytogenetics. 9 (30); 4-8. DOI:https://www. omicsonline.org

Micieta, K. \& Murin, G. (2018). Microspore analysis for genotoxicity of a polluted environment. Environ. Experimental Biol. 36 (1) : 21-27. DOI: https://jeb.biologists.org

Rangaswamy,N., Subramayan, J. \& R. Tandon (2019). Microspore tetrad analysis - Can either type of microsporogenesis engender tetrads of all configurations? DOI: http://www.botany. unibe.ch/paleo/pollen_e/aperture.htm; 25-01-2019

Suripto \& Sukarso, A.A. (2003). Studi awal bioindikasi pencemaran udara melalui analisis mikrospora untuk kawasan Kota Mataram. J. Biologi Tropis. 4(2):14-26. DOI: http://jurnalfkip. unram.ac.id/index.php/JBT

Suripto (2019). Kepadatan Arus Lalu Lintas Jalan Raya dan Tingkat Kebisingan Di Kota Mataram. Unpublished Report Himpunan Kertas Kerja Mata Kuliah Pengetahuan Lingkungan Program Studi Biologi Universitas Mataram.

UNEP (2015). Atmospheric pollution. In: The State of The Environment. UNEP. Nairobi. Kenya. p 1-8. 48, Vassileos Konstantinou Ave., 11635 Athens https://web.unep.org/unepmap/search/node

Zar, J.H. (2007). Biostatistical Analysis $5^{\mathrm{TH}}$ ED. PrenticeHall, Inc. Englewood Cliffs. New Jersey. ISBN:0131008463 